\title{
HELEN CALDWELL, CECIL HEMLEY AND THEIR DELIBERATIONS OVER DOM CASMURRO 1
}

\section{HÉLIO DE SEIXAS GUIMARÃES}

Universidade de São Paulo

São Paulo, São Paulo, Brasil

\begin{abstract}
Between September and December 1952, Helen Caldwell, who had just finished her translation of Dom Casmurro into English, and editor Cecil Hemley, who was preparing the publication of the book at the Noonday Press, kept up an intense correspondence. In reviewing the details of the translation, they also expressed their disagreements regarding the until-then prevailing interpretation of the novel, and in so doing set the ground for an alternative reading of the story about Bento Santiago and Capitu. In the letters airmailed between New York and Los Angeles, these two minds formulated the dilemma that would become the greatest commonplace derived from reading a literary text in Brazil: "In the end, did Capitu cheat on Bento or not?" Based on the correspondence between Helen Caldwell and her editor, and paying particular attention to the appended four letters presented in their original format, this article reveals how the interpretation that would change the reading of the most canonical book and author in Brazilian literature was forged.
\end{abstract}

Keywords: Machado de Assis; translation; editing; reception; Helen Caldwell; Cecil Hemley.

\section{HELEN CALDWELL, CECIL HEMLEY E OS JULGAMENTOS DE DOM CASMURRO}

Resumo: Entre setembro e dezembro de 1952, Helen Caldwell, que acabara de concluir a primeira tradução para o inglês de Dom Casmurro, e o editor Cecil Hemley, que preparava a publicação do livro pela Noonday Press, mantiveram intensa correspondência. Em meio à revisão de detalhes da tradução, expressaram também suas discordâncias em relação à interpretação até então dominante sobre o romance, lançando as bases para uma leitura alternativa da história de Bento Santiago e Capitu.

\footnotetext{
${ }^{1}$ The research that made locating the documents that underpin this article possible was conducted at the New York Public Library in New York City, USA, with support from the Tinker Foundation and at the Center for Portuguese Studies of the University of California, Santa Barbara, USA, with support from FAPESP, The São Paulo Research Foundation. I am thankful to Robin Hemley for granting me permission to publish the letters of Cecil Hemley, his father.
} 
Na correspondência entre Nova York e Los Angeles, formulava-se o dilema que se tornaria o maior lugar-comum produzido a partir da leitura de um texto literário no Brasil: "Afinal, Capitu traiu ou não traiu?" Tomando como base a correspondência entre Helen Caldwell e seu editor, e examinando especialmente quatro cartas traduzidas e incluídas em anexo, este artigo mostra como se forjou a interpretação que mudaria a leitura do livro e do autor mais canônicos da literatura brasileira.

Palavras-chave: Machado de Assis; tradução; edição; recepção; Helen Caldwell; Cecil Hemley.

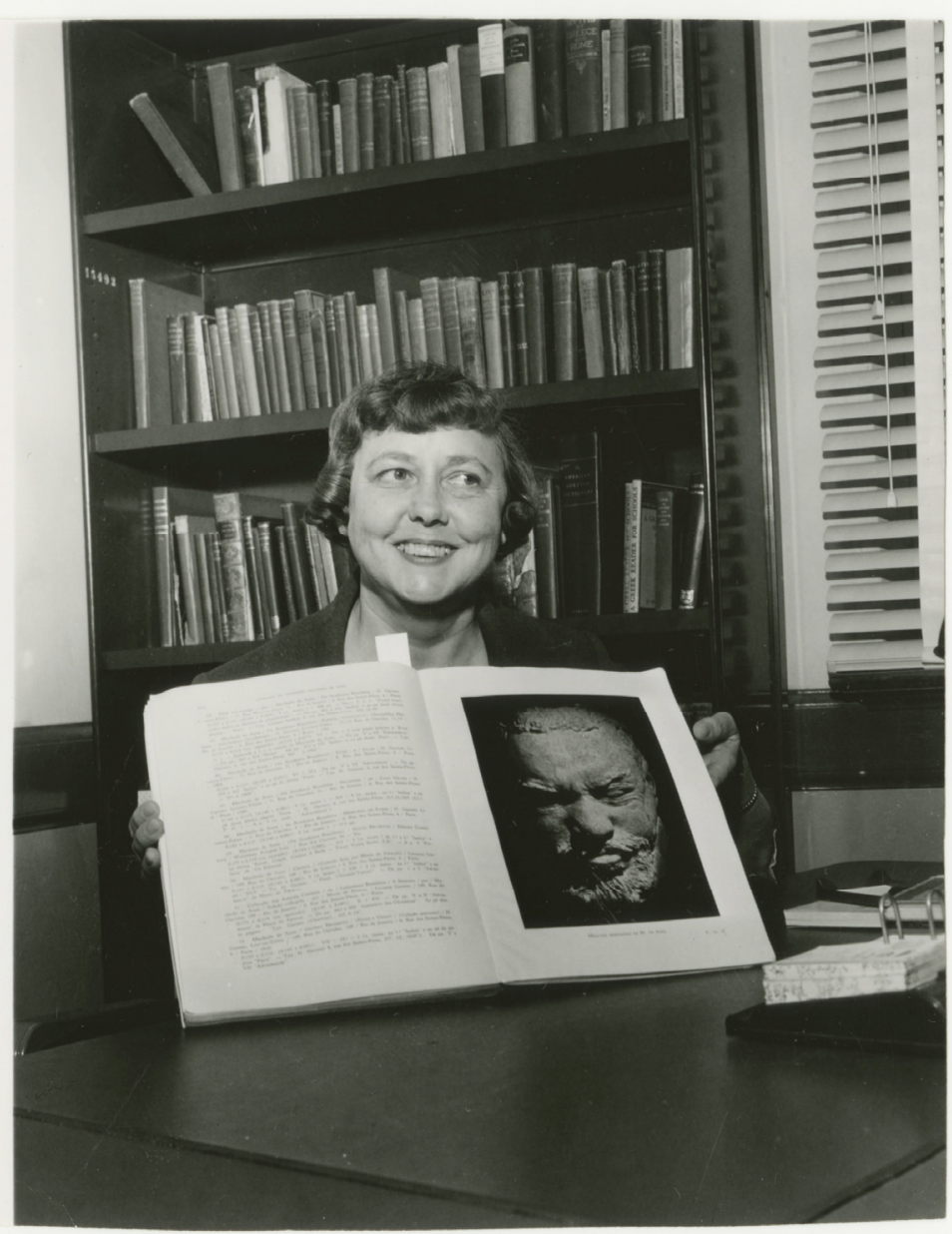

Helen Caldwell, senior lecturer in Classics, critic and translator, shows an image of Machado de Assis's death mask; picture taken in Los Angeles, in 1959. Credit: UCLA Library Special Collections 
For the spirit of Prometheus is not dead, the spirit of Adam is not dead; that "ancient instinct of resistance to authority" resides in the depths of all our natures.

Helen Caldwell, Micho Ito - The Dancer and his Dances.

I n a letter dated September 20, 1952 to Cecil Hemley, the editor of the first translations of Machado de Assis's novels published in the USA, Helen Caldwell, a Senior Lecturer in Latin and Greek, who at the time was reviewing her translation of Dom Casmurro, questioned the male character and presented a diagnosis for him: "Certainly Dom Casmurro is no pessimist. He is a neurotic, thank God, with a beautiful split down his psyche - but he's a robust neurotic." ${ }^{2}$

This comment acted as the trigger for editor Cecil Hemley to respond with a completely unorthodox reading of the novel. On October 8, 1952, Hemley expressed his opinion frankly but also carefully, since it amounted to an affront to William Grossman, who earlier that year had published the first translation of Memórias póstumas de Brás Cubas into English, titled Epitaph of a Small Winner (1952), with the very same publishing house, the Noonday Press. The New York editor outlined an interpretation that later Caldwell (1960) would develop in her book, The Brazilian Othello of Machado de Assis.

Dr. Grossman believes that Dom Casmurro has actually been betrayed. I can find no objective evidence whatsoever to back up this contention in the story. The most that can be said is that a betrayal was not impossible, since one can never disprove a negative. But Bento's evidence is extremely tenuous - a look and a similarity in appearance. Now Machado is very careful to undermine this evidence. Besides which he gives us indication after indication of Bentho's [sic.] jealousy. He compares Bentho to Iago and to Othello. And I suspect that the ironic Machado knows very well what he is doing. Capitu, it is true, has been shown clever enough to engineer a deception, i.e., the deception of Bentho's mother in the first part of the book. But is this deception comparable to the deception of adultery? I should think not. Add to this the fact that the construction of the book would be all wrong if this was the story of a mere triangle, and I think the evidence is overwhelming that Dr. Grossman's interpretation must be in error. If Machado had wanted to tell the story of a "sensitive man deceived" why did he

${ }^{2}$ Letter from Helen Caldwell to Cecil Hemley dated Sep. 22, 1952. 
compress all that concerns this into one less than a third of the book? Bentho, as you say in one of your letters, is a neurotic. He dismisses his wife, dreams of killing the child, without even permitting an explanation. His tragedy is that most likely he has allowed his neurosis to destroy a happy marriage, deprive him of his child, poison his life.

And there is no possibility of ever controverting him since at the end of the book all the principals, with the exception of himself are dead. I say most likely because on the evidence given it is not impossible that Capitu was unfaithful - only not very probable. The technique Machado uses to relate the story (narration by the jealous husband) makes for the essential ambiguity - an ambiguity, which under the circumstance, cannot be cleared up.

Is this more or less your view? If not, how do you interpret the novel? This whole matter, it seems to me, should be thrashed out, before I write the material for the dust-jacket. ${ }^{3}$

The passage lays out the interconnected issues of the doubt surrounding the adultery and the problematic status of the narrator in the first person, who simultaneously casts doubt and makes clarity on the matter impossible.

Helen Caldwell's answer would come four days later. She not only demonstrates that she is in full agreement with Hemley's reading, in totto and in the details, as she wrote, but also suggests that she had been cultivating a similar interpretation regarding the love story between Bento Santiago and Capitu. In her mind, it was the obvious interpretation: "I believe as you do that the whole story is in the book and that an adult should be able to analyze it. I believe further that even a sensitive child should be able to feel the truth." ${ }^{4}$

In the same letter, she states that she has found no resonance for her opinion among Brazilian critics, which led her to a certain exasperation and to the project of writing a book where she would lay out her perspective on Dom Casmurro:

No Brazilian critic that I know of has really gone into the matter of whether Capitu was unfaithful or not, or attempted a serious analysis of the book, but many, if not most, of them assume her infidelity. When I discovered this topsy-turvy situation in our great sister republic I began to doubt my own sanity, to re-examine the book and look for accessory

\footnotetext{
${ }^{3}$ Letter from Cecil Hemley to Helen Caldwell dated Oct. 8, 1952.

${ }^{4}$ Letter from Helen Caldwell to Cecil Hemley dated Oct. 12, 1952.
} 
evidence in Machado's other writings, the collected and the few uncollected that I could lay my hands on. I assembled such a wealth of material that I decided to write a book using my interpretation of Dom Casmurro as a spring board to explain the method and purpose of Machado de Assis not only in that novel but in the others as well. ${ }^{5}$

The letter also reveals that as early as 1952 she had already defined the argument and the title of The Brazilian Othello of Machado de Assis, which she would publish eight years later with the complete and detailed defense of Capitu's "innocence."

Even though it is impossible to pin-point the date when Helen Caldwell took interest in Machado de Assis, we know from her correspondence that she read Dom Casmurro and most of the work of Machado de Assis for the first time shortly after she started studying Portuguese at the University of California, Los Angeles (UCLA) under Professor Marion Zeitlin in 1942 and 1943.

By 1950, she had already collected a vast array of material about the life and work of Machado de Assis, as is made clear in the document she presented in October 1950 at the International Colloquium on LusoBrazilian Studies in Washington, D.C. In said document, she displayed her broad and deep knowledge of the latest developments in Machadian studies upon proposing the development of a complete bibliography (along the lines of the one that José Galante de Sousa would publish in 1955) and the organized publication of the works of Machado de Assis. ${ }^{6}$ In October 1951, she presented a paper under the title "Our American Cousin, Machado de Assis," in which she proposed the comparison between Machado and Shakespeare. ${ }^{7}$

At that point, her incursions into the Machadian meanderings led her to anything but favorable views on Brazilian criticism, as we can read in that same letter:

Brazilian writers - aside from giving out vague generalities on his greatness - have, for the most part, devoted themselves to explaining his work in the light of his myopia, epilepsy, negro blood, etc. - the

\footnotetext{
${ }^{5}$ Letter from Helen Caldwell to Cecil Hemley dated Oct. 12, 1952.

${ }^{6}$ This material was published in 1953 by the Vanderbilt University Press, Nashville, under the title, Proceedings of the International Colloquium on Luso-Brazilian Studies, Washington, October 15-20, 1950, under the auspices of The Library of Congress and Vanderbilt University/Atas do Colóquio Internacional de Estudos Luso-Brasileiros.

${ }^{7}$ The translated essay was published in Machado de Assis em linha (CALDWELL, 2013).
} 
abusive and scurrilous Sylvio Romero even wrote that he "stuttered" in his style. They have frivolously bandied from pen to pen hear-say and unfounded imagining which a simple reading of his books would have disproved. It's not that most of them don't admire him; but they are overwhelmed and baffled by him, call him their "myth," their "enigma, "Sphinx."

If we forgive the unfriendly tone, we can appreciate Caldwell's fine perception that one of the reasons for the omissions made by Brazilian critics was due to the fact that they felt subjugated to Machado de Assis's authority. Associating Machado's narrators to the writer himself, the Brazilian readers often transferred Machado's authority to his narrators. This made it very difficult indeed to produce a reading that contradicted the versions that Brás Cubas, Dom Casmurro or Counselor Ayers presented of their stories, since, within such a mental framework, it would imply questioning or discrediting the great writer Machado de Assis, who at that point had been turned into a national monument.

No matter how dedicated and loyal Caldwell was to Machado de Assis, at no point did she ever appear to be subjugated to his monumental figure.

Regarding her loyalty, there are two occasions where she made herself quite clear on the matter.

As early as 1953 she had already declared:

As for my interest in Dom Casmurro's fate - Since I'm not the author but more like an impresario, I have no reticence in telling anybody how wonderful it is. Besides, there is my missionary zeal (amounting to fanaticism) to place the book in every red-blooded American's home. ${ }^{9}$

In 1966 she declined an invitation from the prestigious publishing house of Alfred Knopf to translate Guimarães Rosa with the following reasoning: "Guimarães Rosa is a fine writer, but I seem to be a one-man woman. I am now attempting a little book about Machado de Assis." ${ }^{10}$

\footnotetext{
${ }^{8}$ Letter from Helen Caldwell to Cecil Hemley dated Oct. 12, 1952.

${ }^{9}$ Letter from Helen Caldwell to Arthur Cohen, dated Feb. 11, 1953.

${ }^{10}$ Letter from Helen Caldwell to William A. Koshland /Alfred A. Knopf Inc., dated Sept. 25, 1966. I thank Antonio Dimas for sharing this finding with me from his research at the University of Texas, Austin.
} 
This loyalty and fearlessness allowed her to engage in the feat of translating Dom Casmurro with remarkable confidence and conviction, shown both in the process and in the result of her translation.

This independence is what allowed her, as we will see, to challenge the narrator's order not to consult dictionaries, to establish the divergence between the dictionary definitions and those proposed by the narrator, and, last but not least, to note that the meaning of casmurro put forth in the novel had been incorporated into some Brazilian dictionaries. In other words, she would make clear how the authority of the narrator would endure over time. Here is her astute observation:

There is an interesting point about the word casmurro. The novel evidently changed the Portuguese dictionaries. Older ones, like Aulete, give only the meaning "stubborn, obstinate, pig-headed" (teimoso, obstinado, cabeçudo). Recent dictionaries add a second meaning, the one given in Chapter 1 of Dom Casmurro, some of them in the identical words, and the Laudeline Freire quotes as illustration the two sentences beginning, "Don't consult your dictionaries."11

This brought the readings that supported the narrator's version of the story full circle. These readings led even lexicographers to lose sight of the interests of their own trade by approving of the fictional narrator's command, obeying him and conveying his authority to the readers of the dictionary. In so doing, the dictionary came to include the possibility of disobeying the lexicographer's authority, thus repeating the effect that the narrator's command produced in the novel.

Caldwell collected all the evidence of the narrator's enormous authority, naturalized over decades by a broad spectrum of readers, including the greatest critics and even lexicographers.

It is precisely the human trait, inherited from Prometheus and Adam, of constantly challenging authority that Helen Caldwell would reclaim in rescuing a phrase from Esau and Jacob that appears in the epigraph of this text, "an old instinct of resisting authority." Interestingly, the phrase in Machado's novel is highlighted in the biography that Caldwell published in 1977 about another object of her devotion, Japanese choreographer Michio Ito, under whom she studied in her youth and to whom she dedicated an entire book, Michio Ito - The Dancer and His Dances (CALDWELL, 1977).

${ }^{11}$ Letter from Helen Caldwell to Cecil Hemley dated Sept. 20, 1952. 
The possibility of an independent perspective on the national classic novel is certainly due to the fact that the viewpoint was that of someone who resisted authority and who cultivated this angle outside Brazilian cultural taboos, which has already been pointed out by critics like John Gledson (1984) and Roberto Schwarz (1991). Additionally, the correspondence between the translator and the editor suggests that the possibility of this alternative perspective was also the result of Caldwell's detailed translation work, which carefully considered each word of the novel.

The dilemmas regarding the novel's title, introduced in a letter dated September 20, 1952, exemplify the extent of the detail involved in the discussion:

I am afraid that I can't be of much assistance on the title. It is so pregnant with meaning for me as it is, that I am like the alchemist with the word "crocodile." Thursday morning when I received your letters, I showed one of them to Glenn Gosling, who is the southern editor of the University of California Press and my local mentor in such matters, gave him an idea of the story and the problem, and left a copy of the ms. with him so that he could read the first pages. He and his staff pondered it the rest of the day and slept on it and came up with the brilliant solution that it would be better not to translate the title, as any translation would be off enough to convey a fake impression - which left me exactly where I was. He did suggest the addition of English words, as "I am Dom Casmurro," which would connote memoirs, egotism, and possibly fiction.

Word by word, she continues her reasoning about the title:

As for the actual translation of the words - For casmurro one could use curmudgeon, which is fairly close in its colloquial meaning and the same type of onomatopoetic word in English as casmurro is in Portuguese, and has this added advantage: the definition of curmudgeon given by the dictionaries is "an avaricious, grasping fellow; niggard, churl," and yet in common usage both of these meanings, I believe, have been lost, so that the word could be used in the text of the translation without altering a word. The dom is worse - a Portuguese title granted only by the king for meritorious service (e.g., to Vasco da Gama for discovering the route to India), confined to the extreme upper crust of the aristocracy and a few clerics, and usually associated with members of the royal family itself. There are, however, even today, a few old nobles floating around Portugal who use the title - which 
generally causes titters. My only suggestions are "His Highness the Curmudgeon," or "Old Curmudgeon, Esquire." And frankly I don't think much of either. There it is tossed back in your lap. I hope you have a brainstorm. ${ }^{12}$

As can be seen in the choice of words, there is a concern not just regarding the meaning, but also the way they sound, if not both, as is the case of curmudgeon.

This type of attention to the text is what led Helen Caldwell to hear the word Moor when she read the name Casmurro, which was intentionally kept in the title of the novel in English.

In this sense, the famous passage of the first chapter:

Não consultes dicionários. Casmurro não está aqui no sentido que eles lhe dão, mas no que lhe pôs o vulgo de homem calado e metido consigo. (ASSIS 1899, p. 2)

was translated as:

Don't consult your dictionaries. Casmurro is not used here in the meaning they give for it, but in the sense in which the man in the streets uses it, of a morose, tight lipped man withdrawn within himself. (ASSIS, 1953, p. 18, my emphasis)

Note that tight lipped man withdrawn within himself would account for translating calado e metido consigo, suggesting the character's taciturn and reserved nature. The word morose seems to appear as an explanatory addition suggesting the interpretation of the novel by the translator, which reinforces from the first chapter, and retrospectively from the title, the connections between Dom Casmurro and Othello, the moor of Venice.

This association between Casmurro and Moor would allow Helen Caldwell to develop the correlations between the jealousy of Bento Santiago and that of Othello, between Capitu's innocence and that of Desdemona and between Machado de Assis's literary greatness and that of Shakespeare. The thesis of The Brazilian Othello was, thus, already contained in the translation of Dom Casmurro, "Like the fruit within its rind," to use a metaphor from the novel itself.

${ }^{12}$ Carta de Helen Caldwell a Cecil Hemley, 20 set. 1952. 
The connections suggested in the translation were made explicit years later in the Brazilian Othello of Machado de Assis, when she writes:

Othello's jealousy turned him into a Moor; Bento's turned him into a "casmurro." For, I believe, Machado de Assis punned on this word: the English word "Moor" and the middle syllable of "casmurro" have practically the same sound. To any one who enjoyed playing upon words as much as Machado de Assis did, such a pun would not be at all impossible - on the contrary, it would be irresistible, and in so doing he had no less a model than Shakespeare himself, who punned on the word "Moor" "more" than once. (CALDWELL, 1960, p. 125)

Regarding the rhythm of the phrases and the construction of the sentences, Caldwell also seeks to stay close to what she believed Machado's intentions were while asserting her interpretation of the novel. Addressing the concerns the editor raised regarding some of the novel's constructions, Caldwell defended her translation like so:

Yes, the last part of the novel is more difficult (though Heaven knows it is all difficult enough). As I have mentioned before, when Dom Casmurro becomes emotionally confused this confusion is reflected in his prose (intentionally, I believe) so that there are many passages which seem like a mixture of Shakespearian soliloquy and Gertrude Stein in her more lucid pieces. This makes pour le sport - but it is tough on a translator, who is placed between two fires. If he does the easy thing, i.e., makes a glib and slick approximation with verbose explanation of what is only a suggestion in the original, the translation becomes superficial - if not false. If he tries to reproduce the emotional chaos of the original he runs the danger of being obscure and of sounding labored. Well, I admit, when I had to choose between the two alternatives I chose the latter, because it is what Machado himself did. [...] And I am sorry you are having so many worries over this roughness. ${ }^{13}$

In this true display of her principles as a translator, Caldwell is not intimidated by the difficulties expressed by the editor, whom she admires and holds in high esteem. She shows the conviction of her commitment to the writer, as well as to her interpretation of the book, thus adopting a position that deviates from what Lawrence Venuti (1995) defines as the

${ }^{13}$ Letter from Helen Caldwell to Cecil Hemley dated Nov. 7, 1952. 
dominant trend in the English-language translation culture, that of the translator's invisibility.

Instead of adopting an attitude of rectifying and domesticating, and thereby erasing the opacity of the source text, Helen Caldwell opts to bank on the discontinuities and inconsistencies of the text in Portuguese, thus reasserting her own interpretation of the novel, based on the psychic condition of what she had defined as a neurotic character.

Throughout the month of October 1952, the translator and the editor keep up an intense correspondence in which they define the basis for the alternative interpretation of the novel. Cecil Hemley forwarded part of this correspondence to Waldo Frank, a prominent Latin Americanist, who had been asked to write the preface to the novel, with the following recommendations to Frank:

I should pass on to you certain correspondence the translator, Helen Caldwell, and I had concerning the meaning of Dom Casmurro. I don't know whether you will agree with our interpretation or not - both Miss Caldwell and I naturally would like you on our side - but it is by no means necessary that you should be. The book is going to press Monday and you should have galleys soon. ${ }^{14}$

In his "Introduction" to Dom Casmurro, Waldo Frank embraces the interpretation shared by Hemley and Caldwell when he refers to "Capitu's innocence or guilt" as "the central ambiguity of Dom Casmurro." Stopping short of taking sides, Frank asserts that "Ambiguity is the book's texture and life vision" (FRANK, 1953, p. 11), thus aligning himself with the view that Hemley had expressed in his letter to Helen Caldwell, in which he refers to the "novel's essential ambiguity."

Here we come to another full circle, that of the alternative reading of the novel, in which the translator, the editor and the critic transformed the Brazilian classic about feminine adultery, until then considered to be a matter of fact, in a novel based on ambiguity, uncertainty and masculine madness.

Well, and the rest?

${ }^{14}$ Letter from Cecil Hemley to Waldo Frank. Carbon copy. Undated, but probably written on Oct. 30, 30 out. 1952. 
Until now, the landmark moment for the extraordinary upending of the accepted interpretation was vaguely associated with The Brazilian Othello of Machado de Assis, in 1960. However, considering what the correspondence between Helen Caldwell and Cecil Hemley reveals, it is clear that we must shift that landmark back to no later than the early 1950s.

As a result, we see that the effects of the interpretive turning point were even slower, more delayed and silenced than we believed until now.

In a culture like that of Brazil, so watchful of and sensitive to its image and name abroad, it is intriguing that there is such a general lack of knowledge about the breadth and longevity of the intellectual project carried out by Helen Caldwell.

The Brazilian Othello is practically the only work by which Helen Caldwell is remembered in Brazil. The very negative view of the Brazilian criticism, the rapture of overinterpretation and the assertion of something that is effectively impossible to prove - that is, Capitu's "innocence" - all of this certainly contributed to casting both The Brazilian Othello of Machado de Assis and its author as extravagant in the field of Brazilian criticism.

Yet, it is just a small part of a much broader picture given the size and scope of her criticism, the overlap between her critical project and her activity as a translator, as well as the impact it had on the reading of the most canonical novel in Brazilian literature.

Even though her reading of the novel, based on her study of the characters and on intentionalism might sound anachronistic for the beginning of the 1960s and old-fashioned since then, and even though some of her interpretive conclusions, such as Capitu's innocence, are questionable, the historical importance of both Caldwell's book and she herself as its author have yet to be thoroughly understood and acknowledged.

Helen Caldwell dedicated over four decades of her life to Machado de Assis, the result of which are her two books of criticism (The Brazilian Othello of Machado de Assis, 1960; Machado de Assis - The Brazilian Novelist and his Novels, 1970), and the translation of four novels (Dom Casmurro, 1953; Esau and Jacob, 1965; Counselor Ayres Memorial, 1972; Helena, 1984), and the co-translation with William Grossman of a volume of short stories (The Psychiatrist and Other Stories, 1963). Caldwell even became an informal representative for everything related to the copyrights for the translation and adaptation of the work of Machado de Assis outside Brazil, including translations into languages other than English, and adaptations for film, which were considered but never carried out. 
With the sale of Noonday Press in the 1960s to Farrar, Straus \& Cudahy Inc., which later became Farrar, Straus \& Giroux, Helen Caldwell appears to have played an important role in transferring the publications surrounding Machado de Assis from New York to California. What marked this move was precisely the publication of The Brazilian Othello of Machado de Assis, by the University of California Press. The publishing house would go on to incorporate five more titles related to Machado de Assis into its catalog, which included very few authors of fiction.

It is not that Helen Caldwell was completely ignored but I would say she has been a muted presence.

There were immediate reactions to her book right after its publication. However, in general, Helen Caldwell's reading was considered to be too "lexicographical," that is, highly dependent on meanings given by dictionaries, which is quite ironic. Furthermore, the critics who expressed themselves first cited the fact that Helen Caldwell, who had not visited Brazil until 1961, lacked "Brazilian life experience," as a reason for her not understanding the book properly. ${ }^{15}$

By the end of the 1960s her name is mentioned in passing in two of the more influential essays on Machado de Assis published at the time, "Esquema de Machado de Assis," by Antonio Candido (1970) and "Retórica da verossimilhança," by Silviano Santiago ([1968] 2000). Candido mentions the alternative interpretation about Dom Casmurro to suggest its irrelevance considering the consequences the character-narrator endured. In the allegation of Capitu's innocence, put forth by Caldwell, Santiago sees critical naivety.

Three decades would pass before critics began to recognize the magnitude of the shock caused by Helen Caldwell's interpretation.

In 1994, Abel Barros Baptista published his essay, "O Legado Caldwell ou o paradigma do pé atrás," in which he identifies The Brazilian Othello of Machado de Assis as the landmark for the beginning of readings of the novels based on mistrust of the narrator, thus establishing a critical lineage that includes Silviano Santiago, John Gledson and Roberto Schwarz. At the same time that Baptista acknowledged how great the consequences of Caldwell's study had been on Machadian criticism, he refuted Caldwell and the entire paradigm she introduced when he pointed out inconsistent arguments and fallacious reasoning.

${ }^{15}$ For details on the immediate reception of The Brazilian Othello by U.S. and Brazilian criticism, see Guimarães (2017). 
Roberto Schwarz (1991) would point out in "A poesia envenenada de Dom Casmurro" that the problem raised by Helen Caldwell was not limited to the interpretation of the novel, but also addressed an issue of reception, which, in turn, referred to a broader and far-reaching cultural problem:

Accidently or not, it was only sixty years after the novel had been published and republished many times that an American academic (because she was a woman? because she was a foreigner? maybe she was a Protestant?) began to look at the figure of Bento Santiago - the Casmurro of the title - with the necessary mistrust. It is as if, for the Brazilian reader, the sordid implications of certain kinds of authority had been less visible. (SCHWARZ, 2012, p. 57-58)

Schwarz touches on what I think is the sensitive part of the issue, showing how the lack of "Brazilian life experience" is precisely what would have allowed the alternative reading by the U.S. critic. It was probably for these same reasons - being a foreign woman, and evidence suggests she was not a protestant, but an atheist, ${ }^{16}$ and having developed her work on Machado de Assis both on the margins of the Department of Spanish and Portuguese and of her institutional role as lecturer of Latin and Greek - that she was vetoed for so long by most Brazilian readers.

The issue surrounding whether Capitu cheated on Bento or not, a concept that Helen Caldwell's book encapsulated, continued to spark reactions from prominent readers, such as Otto Lara Resende (1992) for whom "suggesting Bentinho is 'our Othello' is pure fantasy. Hare-brained, in fact." and Dalton Trevisan (2013), who in his "Capitu sem enigma" and several of his fictional texts ridicules Capitu's alleged innocence.

In 1999, upon recomposing the controversial reception of Dom Casmurro, specifically regarding whether there was any adultery, Folha de $S$. Paulo, one of the most prominent newspapers in Brazil, gathered passages by José Veríssimo, Lúcia Miguel Pereira, Augusto Meyer, Antonio Candido, Silviano Santiago, Antonio Callado, Dalton Trevisan, Otto Lara Resende,

\footnotetext{
${ }^{16}$ August Frugé, when remembering his visit to Brazil in 1961, on which he was joined by his wife and by Helen Caldwell, said, "I get ahead of myself once more but would like to record that Helen Caldwell, who had never before been to Rio de Janeiro but knew the streets from her studies, led Susan and me through the old districts where Machado de Assis had lived and worked in the century before. And in Salvador da Bahia, the old northeastern capital city, the three of us got caught up in a popular religious procession, hundreds of people who had walked and sung from the basilica of Bon Fim in the outskirts, five miles away. They filled the narrow street from wall to wall and swept us along, with Helen singing 'Ave María' at the top of her voice and muttering under her breath, 'And I come from five generations of atheists.'" (FRUGÉ, 1993, p. 113)
} 
John Gledson and Roberto Schwarz. It is symptomatic that the report did not mention a word about or by Helen Caldwell, even though she clearly is the major point of reference implied in the passages of most of the critics cited (CAPITU, 1999).

However, there is nothing more telling of this silencing than the fact that there is a span of 42 years between the publication of Caldwell's The Brazilian Othello in English and its translation into Portuguese in 2002.

On the eve of the book's $60^{\text {th }}$ anniversary, Helen Caldwell's voice continues to be muted and anonymous in the greatest commonplace ever produced regarding a literary occurrence in Brazil - Did Capitu cheat on Bento or not? - whose creation was most influenced by Caldwell's hand.

This leads us to consider how the devices for silencing dissonant and daring voices, put in play in Dom Casmurro, persisted in the translation of the novel and in its international diffusion by making the loyal translator invisible and by silencing the audacious critic. 


\section{THE LETTERS}

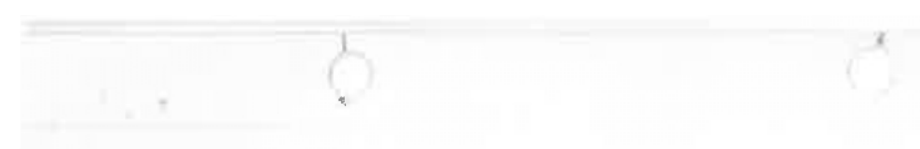

UNIVERSITY OF CALIFORNIA

DEPARTMENT OF CIASSICS LOS ANGELES 24, CAIIFORNIA

Mr. Cecil Hemley

Editor in Chief

The Noonday Press

77 Irving Place

New York 3, New York

Dear Mr. Hemley:

It was very flattering to recelve $t$ wo letters from you in one mail, even if you did repeat yourself somewhat. And thank you for your kind words about Dom Casmurro. I tried to be true to Machado de $A_{8}$ is in letter and spirit, for he has been my friend and constant companion for almost ten years. In addition, M.A.Zeitlin of our university, who is a fine Portuguese scholar and has a hawk's eye, carefully read the translation and the original together, chapter by chapter. And even now I am going over it once more with Ilda Stiohini (the Portuguese actress) to catch any nuances, especially of humor, or allusions that $I$ may have missed. I read the Portuguese aloud shile she follows the English.

I am afraid that I can't be of much assistance on the title. It is so pregnant with meaning for me as it is, that I am like the alchemist with the word "crocodile." Thursday morning when I received your letters, I showed one of them to Glenn Gosling, who is the southern editor of the University of California Press and my local mentor in such matters, gave him an idea of the story and the problem, and left a copy of the ms. With him so that he could read the first pages. He and his staff pondered it the rest of the day and slept on it and came up with the brilliant solution that it would be better not to translate the title, as any translation would be off enough to convey a false impression--which left me exactly where I was. He did suggest the addition of English words, as "Iam Dom Casmurro," which would connote memoirs, egotism, and possibly fiction.

As for the actual translation of the words-For casmurro one could use curmudgeon, which is fairly close in its colloquial meaning and the same type of onomatopoetic word in English as casmurro is in Portuguese, and has this added advantage: the definition of curmudgeon. given by the dictionaries is "an avaricious, grasping fellow; niggard, churl," and yet 
By now you are probably thanking your lucky stars that New York and West Los Angeles are 3000 miles apart. I promise to be more prompt and less long-winded another time. Anything I can do, let me know. You may say frankly what you please without fear of hurting my feelings, for, though an amenable mouse in most respects, where Machado de Assis is concerned I am such a complete megalomaniac as to feel that no one on earth, or any place else, truly understands and appreciates him but me.

Thank you for your nice letters.

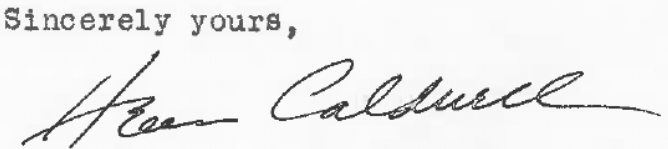

P.S. I have given the copy of the translation to our

Brazilian consul to send to the Ministry, and have

written his brother-in-law who is there and has

(happily) just been promoted.

If you ever want to reach me by special delivery

or phone, my apt. is better: 1022 Tiverton Av.,

LOs Angeies 24. Phone: ARIZONA 9-1890. No one

is in the apt. when I am not there so that you

could make a sta-to-sta call. 


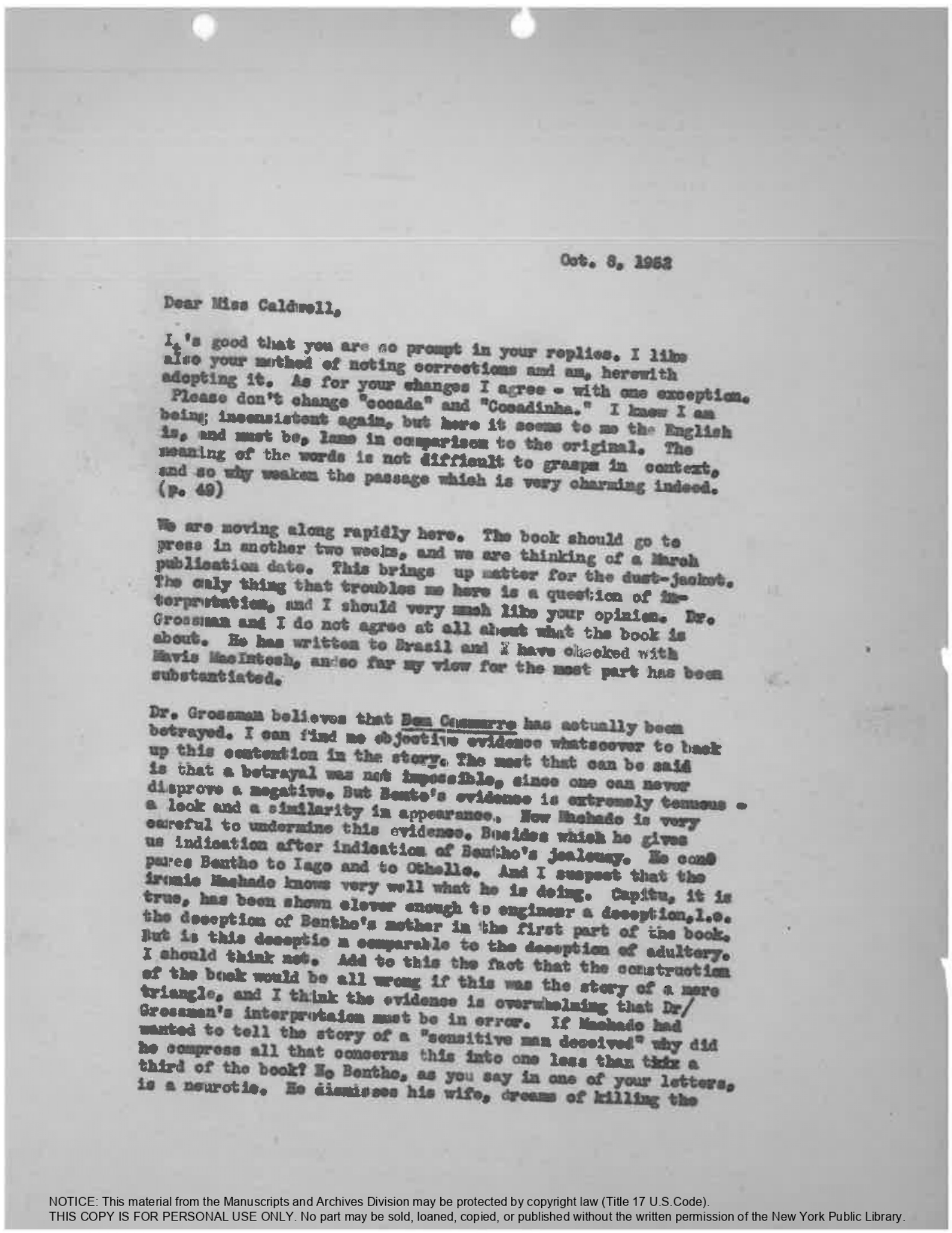




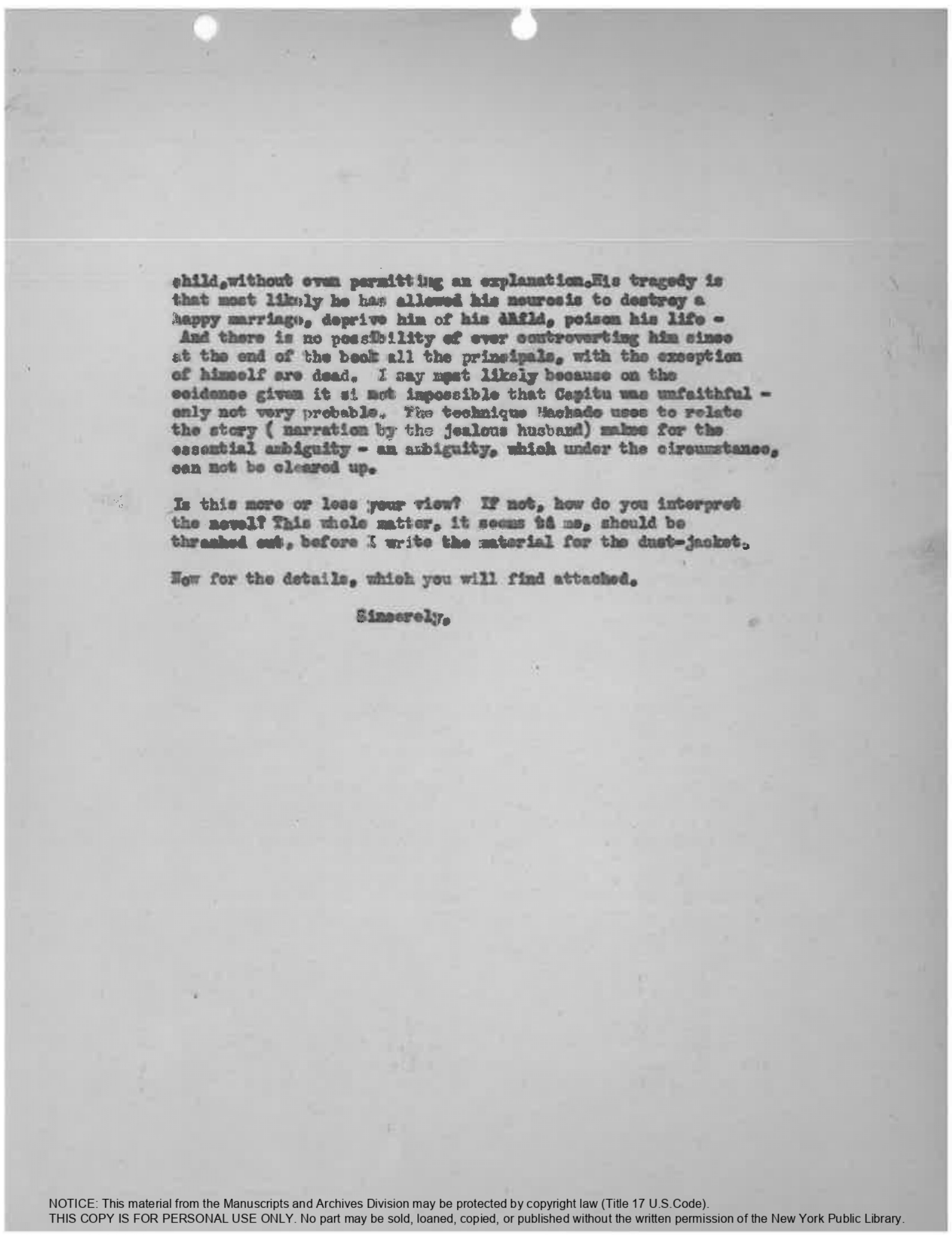




\section{UNIVERSITY OF CALIFORNIA}

DEPARTMENT OF CLASSICS LOS ANGELES 24, CALIFORNIA
October 12, 1952

Dear Mr. Hemley:

There is nothing "to thrash out" about the interpretation of the book: your analysis is correct in toto and in all details. And I am very happy that Machado de Assis has an intelligent and sympathetic publisher for his English Dom Casmurroit is more than he had while he lived, for the Portuguese one. I believe os you do that the whole story is in the book and that an adult should be able to analyze it. I believe further that even a sensitive child should be able to feel the truth. When it comes to Brazilian "criticism," well_- Hundreds of books, articles, essays, monographs, etc., have been written on Machado de Agsis. No Brazilian critio that I I know of has realiy gone into the matter of whether Capitu was unfaithful or not, or attempted a serious analysis of the book, but many, if not most, of them assume her infidelity. When I'discovered this topsyturvy situation in our great sister republic I began to doubt my own sanity, to re-examine the book and look for accessory evidence in Machado's other writings, the collected, and the few uncollected that I could lay my hands on. I assembled such a wealth of material that I decided to write a book using my interpretation of Dom Casmurro as a spring board to explain the method and purpose of Machado de Aseis not only in that novel but in the others as well. I had actually betrun the writing when Mavis MoIntosh sidetracked me into this translation. But I am still working at it. The title is (I think) "The Brazilian Othello of Machado de ABsis" - which will indicate to you the conolusion to which my discoveries led me.

To come back to Brazilian "critics":- One oritio, a rather good one, José Veríssimo, contemporary and friend of Machado de Assis, though he seemed on the whole to believe in Capitus infidelity, did make a vague suggestion that Bento's hatred mex might zaxe make his testimony suspect. But do not let the Brazilian "critics" influence you. There has been no serious study of Machado de Assis. Brazilian writers-eside from giving out vague generalities on his greatress-have, for the most part, carifine devoted themselves to explaining his work in the light of his myopia, epilepsy, negro blood, etc.-the abusive and scurrilous sylvio Romero even wrote that he "stuttered" in his style. They have frivolously Q Que urderan eritic makes mentim | this for

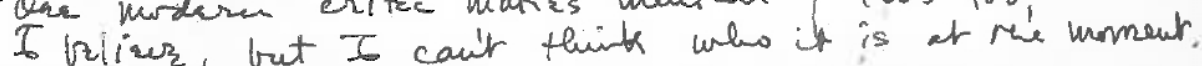
NOTICE: This material from the Manuscripts and Archives Division may be protected by copyright law (Title 17 U.S. Code). 
DEPARTMENT OF CLASSICS LOS ANGELES 24, CALIFORNIA

bandied from pen to pen hear-say and unfounded imaginings which a simple reading of his books would have disproved. It's not that most of them don't admire him; but they are overwhelmed and baffled by him, call him their "myth," their "enigga," "Sphinx." The few critics that have had good and penetrating ideas have not followed them up. To date Brazil has produced no biography of Machado de Assis, big or little, which does not abound in questionable information, no bibliography, or partial bibliography, worth a hang. (Iucia Miguel Pereira does have a good bit of bibliographioal material scattered through her book.) In 1939 the Instituto Nacional do livro announced that it would publish a 2-vol, bibliography. In 1948 I wrote Augusto Meyer, its director, and asked about the progress of this bibliography. Although he wrote me 2 letters and made me a present of a couple of books on Machado de Assis, he did not anwer my question. The only real bibilography I know of is the one in Benj. Woodbridge Jx.'s Ph.D. thesis on Machado de Assis (Harvard, 1949), and he did not pretend to make it complete.

This is not wild facy on my part; Woodbridge feels even more strongly about the situation than I do. $T$ wo years ago I wrote a little paper on the need for scholarship on Machado de Assis for the International Colloquium on Luso-Brazilian Studies, held in Washington, D.C. Mr. Woodbridge presented my paper, discussed it in Portuguese, stressing and amplifying the points from his own knowledge and bitter experience. Although there were between 300 and 400 "scholarg" present, and a good percentage of them Brazilians, there was no dissenting volceand they were a rather argumentative lot too.

The reason for the confusion in Brazilian criticism of Machado de Assis is multifold and goes back to his own lifetime--some of it I undergtand some not. But the reason for the misconception about the BentoCapitu episode, I believe, is primarily this. The character of Dom Casmurro becomes so real that the reader is tempted to identify him with Machado de Assis, and this of course throws Dom C's whole narrative out of perspective. Machado created Dom Casmurro, and let him tell his own story and, like many another criminal, tip his own hand. Machado de Assis' characters are Machado de Assis probably in about the same degree that liacbeth, Falstaff, Juliet and Dame Quickly are Shakespeare. And I find that Dom 
DEPARTMENT OF CLASSICS

LOS ANGELES 24, CALIFORNIA

Casmurro has less of Machado de Assis in him than characters from some of the other works. In fact, I believe that Machado studiously kept in the background and left the field to Dom 0 . There is only one place in the book where I efen euspect that I get a glimpse of Machado de Assis-mand that is in the little satire on Dom Pedro II, philanthropist and patron of the arts and sciences, whom many Brazilians used to call "Pedro Bananas." The daydream of course is in keeping with Bentols weakness for relying on miracies, but the humor seems to me to have a lighter touch, a little more abandon, more In the style of Machado de Assis than in that of Dom Casmurro. And I wouldn't wonder if Machado had let himself go a bit here. (No one, by the way, to my knowledgex, has ever adverted to this little gem as a satire, and yet it's not the onIy time Machado de Assis took a poke at the good old emperor.)

Well, you'll know better another time than to ask me my opinion.

Enclosed are 4 pages of textual criticism. I am glad that your ife is going over the translation too. The more the merrier.

Perhaps I should mention to you that in the Portuguese Dom Casmurro the chapter headings are listed in a table of contents at the back of the book. I omitted them from "the translation because they seem to me like little bridges leading from the last part of one chapter into the next. As titles Iisted on a page, each divorced from what immediately precedes in the text, I think they are rather meaningless; and in the inglish, where they would be put at the betinning, would be just so much stuff to wade through in getting to the etory. I have no terribly strong feeling about the matter, however, if you want to preserve a table of contents.

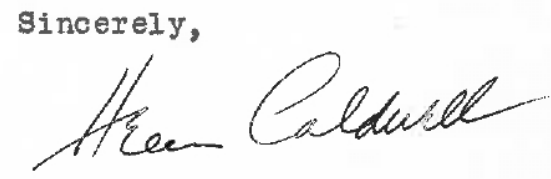




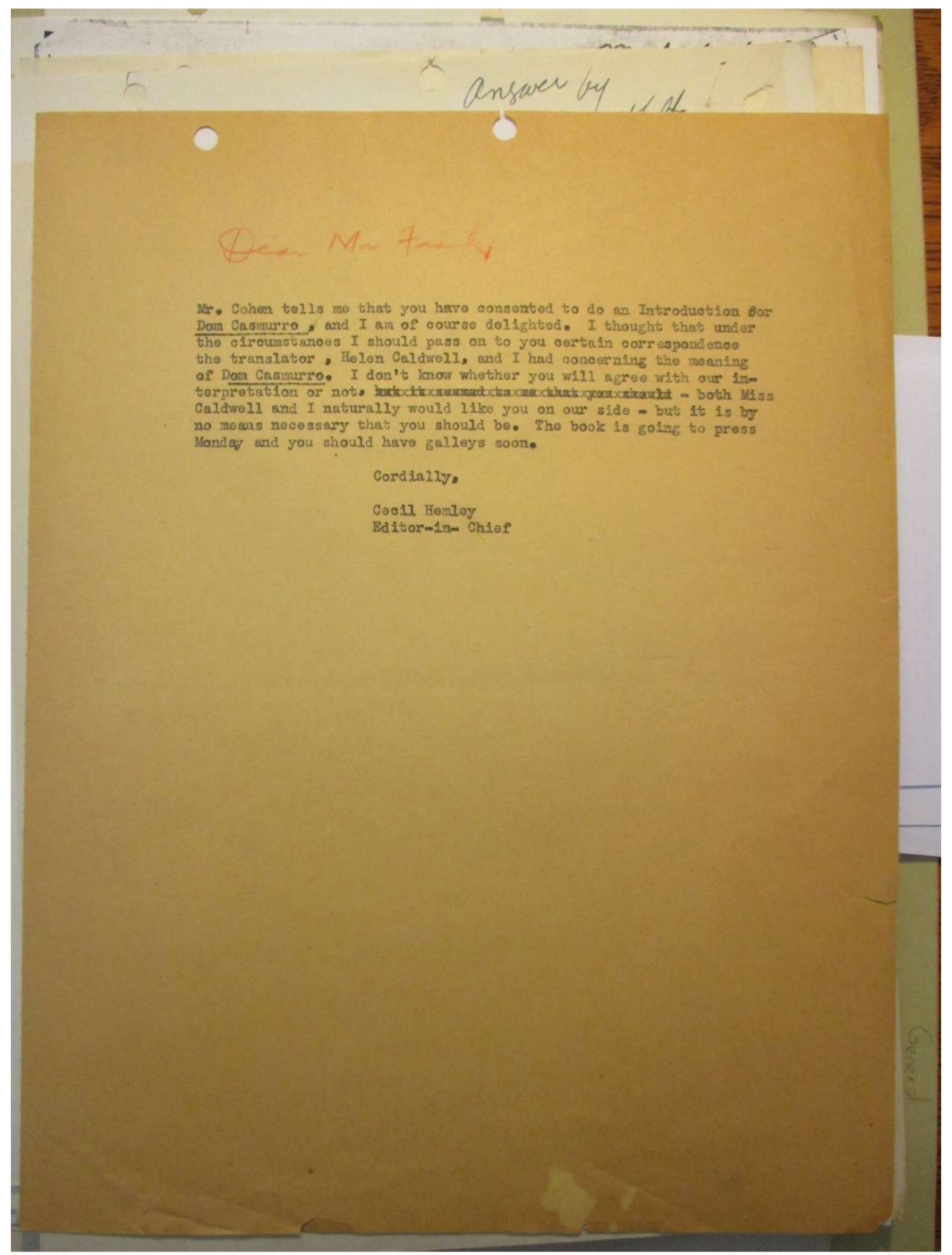




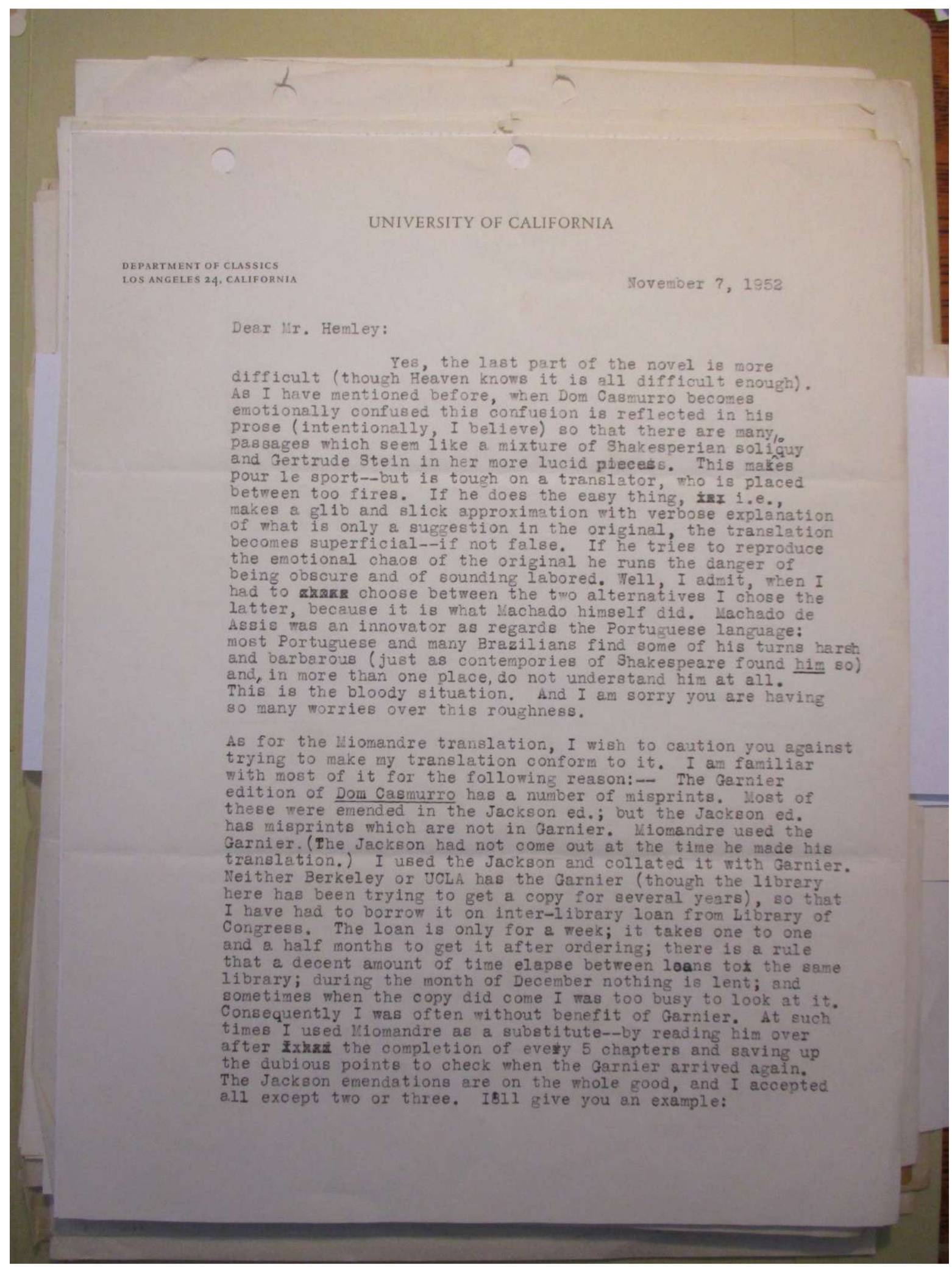


In ohapter CXV Garnier hes "tristezas de Olympio" - which makes no sense. Olympio is a family name, there rag one fairly well known Brazilian writer who bore it, but it still doesn't make sense. (Miomandre kept 1t.) The Jackson emends to "tristezas do 0lympo" and it becomes a clear alusion to the Lusíadas, which fits.

In addition to these textual differences-- Miomandre has made some curious slips. I'll give you a few examples from the last part of the book, which I happen to have marked:4.

Ch. CXIIII he ha,s "grand'mère" where he should have "grand-père" i.e., he read avó for avô.

CXV "ou de vieillesse de pensionnaire". The Portuguese is "ou de ancianidade vigosa, à escolha..." He must have read "à escolar" for texeakmax" a' escolha" and left out "viçosa". It completely changes the sense of course.

aXYIIIXz CXVII "Je haletais un peu, mais peut-être à cause de la mer, qui était à demi agitée." The haletais should be Fesplrsig" and the "qui était à demi agitée" should be

"je haletais un peu", as one can see from the preceding sentence.

CXVIII "intimité" Apparently he read "Íntimo" for "intimativo", and "intimativo" has nothing to do with"intimité" (it has the same base as English "intimidate").

CXXXVI tamxx "sa main sur la hanche" for "a mão nas costas da cadeira"-which means "his hand on the back (or shoulder) of the chair"and nothing else; but if he had doubts all he had to do was turn back to ch. CXX "a mão esquerda no dorso de uma cadeira.", which he himself translated "la main gauche sur le dossier d'une chaise." The figure in a photograph could harily be expected to change ite position, even for Dom Casmurro.

In addition to such type of error, he has a way of altering the person and number of verbs and pronouns, for example: CXLIV "naturellement $11 \mathrm{~g}$ s'étonnaient de cét intrus. " should be "il s'étonnait". Dom $C$. is speaking of one tree. The punotuation in the Portuguese makes this absolutely clear, "A casuarina era a mesma. que eu deixara ao fundo, mas o tronco, em vez de recto, como outr'ora, tinha agora um ar da de ponto de interrogaça; naturalmente pasmava, do intruso." "pasmava" is sing. CXLV "je luí expliquai qu'il avait réellement peu changél skraxx "il avait" should be "j'avaig" --which is also pretty clear from the context as well. OXXXIV "quolque te voltigeasse avec elle" should be "quolque elie voltigeât avec elies,"

1 would be inclined to regard these as printer's errors if they were not so numerous. (It was probably the frequency of these two types of slip that caused the tranglation to be so badiy panned in Brazil, for most educated Brazilians know French well.) 


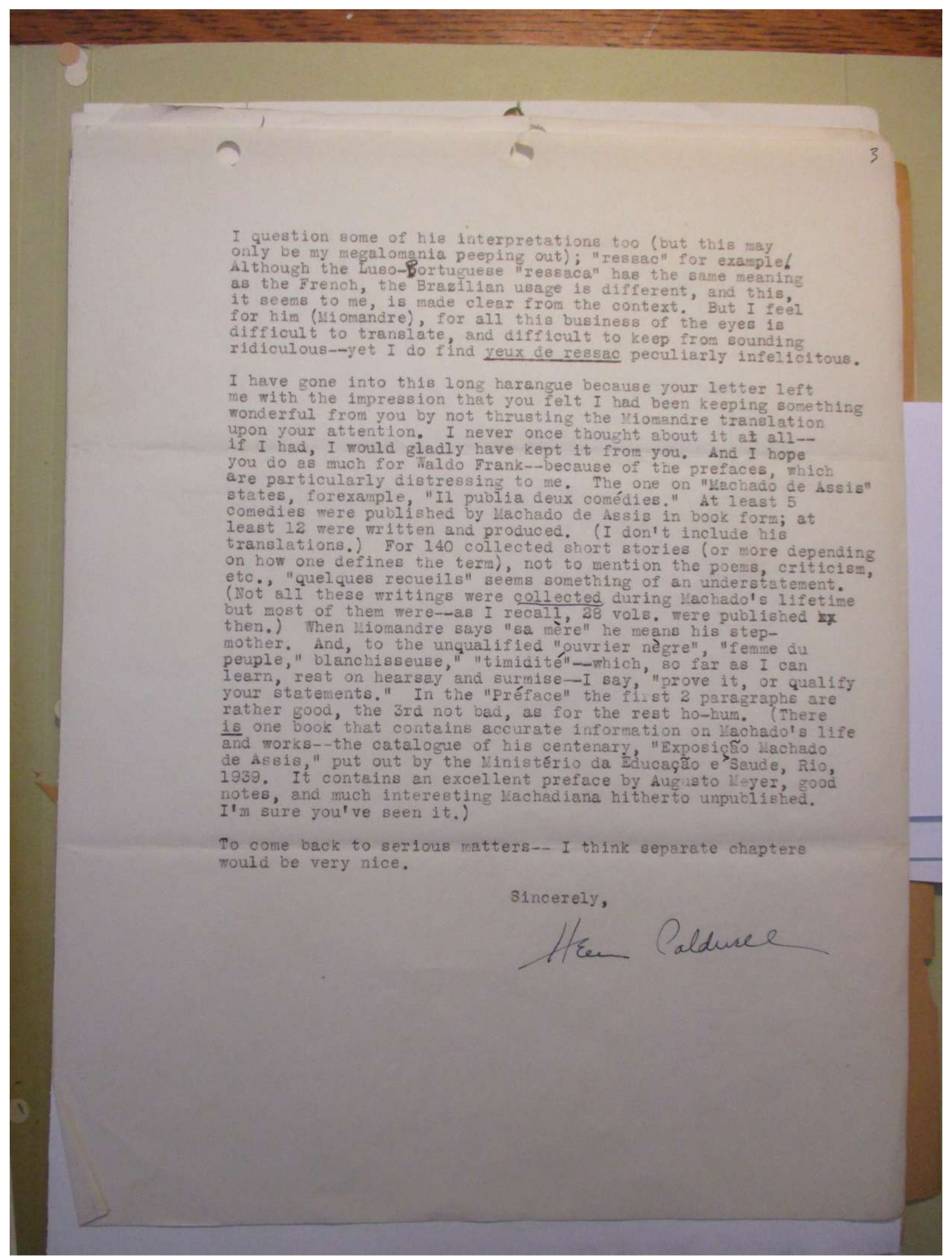




\section{References}

BAPTISTA, Abel Barros. O Legado Caldwell ou o paradigma do pé atrás. Portuguese Studies, Santa Barbara, n. 1, p. 145-177, 1994.

ASSIS, Machado de. Dom Casmurro. Rio de Janeiro: Garnier, 1899.

Dom Casmurro. Translated by Helen Caldwell with an Introduction by Waldo Frank. New York: The Noonday Press, 1953.

CALDWELL, Helen. The Brazilian Othello of Machado de Assis. Berkeley; Los Angeles: University of California Press, 1960.

. Michio Ito - The Dancer and his Dances. Berkeley; Los Angeles: University of California Press, 1977.

O Otelo brasileiro de Machado de Assis: um estudo de Dom Casmurro. Trad. Fábio Fonseca de Melo. Cotia: Ateliê Editoral, 2002.

. Nosso primo americano, Machado de Assis. Machado de Assis em LinhaRevista Eletrônica de Estudos Machadianos, São Paulo, v. 6, n. 11, p. 1-13, jun. 2013. Disponível em <http://www.scielo.br/scielo.php?script=sci_arttext \&pid=S1983-68212013000100002\&lng=pt\&nrm=iso>. Acesso em: 09 maio 2019. doi:10.1590/S1983-68212013000100002.

CANDIDO, Antonio. Esquema de Machado de Assis. In: Vários escritos. São Paulo: Livraria Duas Cidades, 1970. p. 13-32.

CAPITU. Folha de S. Paulo, Caderno Mais!, São Paulo, 28 mar. 1999. Disponível em: $<$ https://wwwl.folha.uol.com.br/fsp/mais/fs28039910.htm>. Acesso em: 8 maio 2019.

FRANK, Waldo. Introduction. In: ASSIS, Machado de. Dom Casmurro. Trans. Helen Caldwell. New York: Noonday Press, 1953. p. 5-13.

FRUGÉ, August. A Skeptic Among Scholars: August Frugé on University Publishing. Berkeley: University of California Press, 1993. Disponível em: <http://ark.cdlib.org/ark:/13030/ft2c6004mb/>. Acesso em: 18 maio 2019.

GLEDSON, John. The Deceptive Realism of Machado de Assis: a Dissenting Interpretation of Dom Casmurro. Liverpool: F. Cairns, 1984. Traduzido como Machado de Assis: impostura e realismo: uma reinterpretação de Dom Casmurro. Trad. Fernando Py. São Paulo: Companhia das Letras, 1991.

GUIMARÃES, Hélio de Seixas. Machado de Assis, o escritor que nos lê. São Paulo: Editora Unesp, 2017.

PEREIRA, Lúcia Miguel. Machado de Assis: estudo crítico e biográfico. 4. ed. São Paulo: Gráfica Editora Brasileira, [1936] 1949.

RESENDE, Otto Lara. Folha de S. Paulo, São Paulo, 8 jan. 1992.

SANTIAGO, Silviano. Retórica da verossimilhança [1969]. In: Uma literatura nos trópicos. 2. ed. Rio de Janeiro: Rocco, 2000. p. 27-46. 
SCHWARZ, Roberto. A poesia envenenada de Dom Casmurro. Novos Estudos CEBRAP, n. 29, p. 85-97, mar. 1991. Publicado também em Duas meninas. São Paulo: Companhia das Letras, 1991. p. 7-41.

. Capitu, the Bride of Dom Casmurro. In: Two Girls and Other Essays.

London; New York: Verso, 2012. p. 57-91.

SOUSA, José Galante de. Bibliografia de Machado de Assis. Rio de Janeiro: Instituto Nacional do Livro, 1955.

TREVISAN, Dalton. Capitu sem enigma. In: Até você, Capitu? Porto Alegre: L\&PM, 2013. p. 13-19.

VENUTI, Lawrence. The Translator's Invisibility: a History of Translation. London: Routledge, 1995.

WOODBRIDGE, Benjamin M. Pessimism in the Writings of Machado de Assis: a Study in the Development of an Attitude and its Expression. Ph.D. Dissertation. Harvard University, 1949.

Translated by John Ellis-Guardiola: john@akatranslation.com

HÉLIO DE SEIXAS GUIMARÃES is an Associate Professor at Universidade de São Paulo (USP) and researcher fellow of Productivity in Research for the CNPq (National Council for Research). He is the author of Machado de Assis, o escritor que nos lê - as figuras machadianas através da crítica e das polêmicas and Os leitores e Machado de Assis - o romance machadiano e o público de literatura no século 19, among other books on Machado de Assis and 19th Century Literature. (D) http://orcid.org/0000-0002-20542689. E-mail: hsg@usp.br

Recebido: 24.05.2019

Aprovado: 27.05.2019 